\title{
SISTEM PENGELOLAAN PENDIDIKAN FORMAL SMP PLUS PADA PANTI ASUHAN AT-THOIBA PEKANBARU
}

\author{
Marzuki \\ STAI Sulthan Syarif Hasyim Siak, Indonesia \\ mpdimarzuki@gmail.com
}

\begin{abstract}
ABSTRAK
Penelitian ini bertujuan untuk mengungkapkan :1) Gambaran dan penjelasan tentang system pengelolaan pendidikan Formal SMP Plus pada Panti Asuhan At-Thoiba Pekanbaru, 2) penjelasan tentang factor-faktor yang mempengaruhi pengelolaan pendidikan Formal SMP Plus pada Panti Asuhan At-Thoiba Pekanbaru. System pengelolaan pendidikan yang dimaksud dalam penelitian ini adalah penelitian yang dilakukan oleh pimpinan dan seluruh staf pendidik dalam melaksanakan program-program pendidikan untuk mencapai tujuan. Dalam pengelolaan pendididikan disini harus mampu mengembangkan tujuh standar yaitu standar isi, standar proses, standar kompetensi lulusan, standar pendidik dan tenaga kependidikan, standar sarana prasarana, standar pengelolaan, standar penilaian pendididik. Metode penelitian yang digunakan dalam penelitian ini adalah dengan menggunakan pendekatan deskriftif kualitatif, karena penelitian ini ingin mengungkapkan pelaku actor-aktor sekolah dalam melaksanakan system pengelolaan pendidikan dilingkungan SMP Plus Pada Panti Asuhan At-Thoiba Pekabaru. Teknik pengumpulan data yang digunakan dalam penelitian ini adalah dengan cara observasi, wawancara, dan pengkajian dokumentasi. Sebagai sumber data penulis menetapkan kepala sekolah sebagai key informan, dan guru-guru dan dokumentasi sebagai informasi pendukung. Teknik analisa data yang digunakan adalah teknik analisis deskriftif kualitatif, terdiri dari reduksi data, display data, dan pengambilan kesimpulan. Ketiga kegiatan tersebut saling terkait antara satu dengan lainnya. Dari hasil penelitian ini menunjukkan bahwa system pengelolaan pendididikan secara teori dan praktek di Sekolah Menengah Pertama ( SMP) Plus pada Panti Asuhan At-Thoiba telah dilaksanakan. Namun dalam pelaksanaannnya masih belum berjalan dengan baik yang sesuai dengan tujuan sekolah.
\end{abstract}

Kata Kunci: Pengelolaan Pendidikan Formal, Panti Asuhan.

\section{A. Pendahuluan}

Pendidikan merupakan proses yang sistematis ${ }^{1}$ (teratur) dan sistematik $^{2}$

1 Alex, Kamus Ilmiah Populer Kontemporer, (Surabaya; Karya Harapan). h 599 (berurutan) yang terdiri banyak komponen. Masing-masing komponen pendidikan tidak bersifat parsial (terpisah) atau berjalan sendiri-sendiri, tetapi harus berjalan secara teratur,

\footnotetext{
${ }^{2}$ Ibid
} 
saling

kerergantungan,

komplementer ${ }^{3}$ (bersifat penyempurnaan /melengkapi), bersinambungan. Untuk itu diperlukan pengelolaan pendidikan yang optimal yang harus dikembangkan berdasarkan pada sistem pengelolaan dan sistem pengajaran yang dirancang secara sistematis, konseptual tetapi praktis - realistis dan fleksibel, baik yang menyangkut masalah interaksi pengajaran, pengelolaan pendidikan, pendayagunaan sumber belajar(pendidikan) maupun penilaian pendidikan.

Pengelolaan pendidikan adalah mengacu pada suatu upaya untuk mengatur (mamenej, mengendalikan) aktivitas pendidikan berdasarkan konsep-konsep dan prinsip-prinsip pendidikan untuk mensukseskan tujuan pendidikan agar tercapai secara lebih efektif, efesien dan produktif yang diawali dengan penentuan strategi dan perencanaan diakhiri dengan penilaian. Dari penilaian akan dapat dimemfaatkan sebagai feedback (umpan balik) bagi perbaikan pendidikan lebih lanjut.

Pendidikan memang bukan konsep atau praktek yang sederhana. Ia bersifat kompleks, menjadi tugas dan tanggung jawab guru yang seharusnya. Pendidikan itu berkaitan erat dengan pengembangan potensi manusia (peserta didik), perubahan dan pembinaan dimensi-dimensi kepribadian peserta didik.

Proses pendidikan selain diawali dengan perencanaan yang bijak, serta didukung dengan komunikasi yang baik, juga harus didukung dengan

\footnotetext{
${ }^{3}$ Ibid. h. 325
}

pengembangan strategi yang mampu membelajarkan siswa.

Pengelolaan pendidikan merupakan suatu proses penyelenggaraan interaksi peserta didik dengan pendidik dan sumber belajar pada suatu lingkungan belajar. ${ }^{4}$ Dalam buku perencanaan yang dikutip dari pendapat Dunkin dan Biddle yang menyatakan " proses pendidikan berada dalam empat variabel interaksi yaitu ;1) variabel pertanda berupa pendidik; 2) variabel konteks berupa peserta didik; 3) variabel proses; dan 4) variabel produk berupa perkembangan peserta didik baik dalam jangka pendek maupun dalam jangka panjang. ${ }^{5}$

Yayasan Panti Asuhan adalah suatu lembaga pendidikan Nonformal yang didirikan oleh setiap individu atau sekelompok orang dalam rangka melanjutkan pendidikan anak kurang mampu dan mewujudkan program pemerintah Wajib Belajar Sembilan Tahun. Ini telah dipaparkan dalam Undang- Undang No. 20 Tahun 2003 Tentang Sistem Pendidikan Nasional pasal 52 yaitu " pengelolaan satuan pendidikan non formal dilakukan oleh pemerintah, pemerintah daerah, dan atau masyarakat". 6

Dalam rangka peningkatan pengelolaan pendidikan formal khususnya di SMP Plus At- Thoiba dilingkup Yayasan Panti Asuhan perlu

\footnotetext{
4 Abdul Majid, Perencanaan Pembelajaran mengembangkan Standar Kompetensi Guru, (Bandung; PT Remaja Rosda Karya). h 111

${ }^{5}$ Ibid.

${ }^{6}$ UU No. 20 Tahun 2003 tentang Sistem Pendidikan Nasional, (Bandung; Fokus Media), 2006. h 26
} 
adanya aspek tujuan dan komponen yang berpengaruh terhadap pencapaian tujuan pengelolaan pendidikan formal di SMP Plus melalui analisis sistem, maka semua itu dapat mencapai hasil yang dicapai akan lebih baik. Dalam hal ini proses sistem pengelolaan pendidikan formal di SMP Plus merupakan bagian yang penting untuk membantu anakanak mendapatkan pendidikan dan juga untuk mencapai tujuan pendidikan.

SMP Plus yang didirikan oleh Yayasan Panti Asuhan At-Thoiba tersebut mempunyai kelebihan dan keunikan, kelebihannya dan keunikannya seperti mata pelajarannya mempelajari semua bidang ada mata pelajaran umum dan ada mata pelajaran khusus seperti:

1. Akidah akhlak

2. Qur'an Hadist

3. Bahasa Arab

4. Nahwu Shorof

5. Tafsir

6. Thareh

Selain itu mereka mempelajari Ilmu-ilmu agama di SMP Plus Panti Asuhan At-Thoiba ada juga kegiatan yang bersifat ekstrakurikuler setiap hari Sabtu anak-anak Panti Asuhan AtThoiba tersebut mempelajari ilmu beladiri, pramuka dan pada hari Minggu mereka mepelajari olah raga, kemudian di SMP Plus Panti Asuhan At-Thoiba mempunyai program membaca Al'qur'an 5 menit sebelum proses belajar-mengajar di mulai.

Yayasan At-Thoiba merupakan lembaga pendidikan yang telah berusaha memberi konstribusi kepada Negara dan juga berusaha untuk meningkatkan tujuan dan fungsi pendidikan. Oleh karena itu perlunya pengelolaan pendidikan formal di Yayasan Panti Asuhan At-Thoibah khususnya SMP Plus. Hal ini merupakan permasalahan yang sangat mendasar dan perlu pemecahannya atau jalan keluarnya.

Berdasarkan observasi yang peneliti lakukan di SMP Plus Panti Asuhan At-Thoiba banyak ditemukan keunikan-keunikan dalam proses pengelolaan pendidikan antara lain;

1. Dalam mengadakan kedisplinan siswa kepala sekolah mengadakan rapat dengan seluruh siswa, orang tua siswa, tenaga pendidik dan tenaga kependidikan.

2. Dalam mengadakan perekrutan tenaga pendidik kepala sekolah dan kepala yayasan Panti asuhan mengadakan rapat secara terbuka dan melibatkan majlis guru.

Dalam mengadakan evaluasi tenaga pendidik dan tenaga kependidikan, baik tenaga pendidik tetap dan tidak tetap kepala sekolah mengadakan secara kontinu atau berkesinambungan dan dilakukan 3 bulan satu kali.

\section{B. Sistem}

System adalah susunan kesatuankesatuan yang masing-masing tidak berdiri sendiri- sendiri tetapi berfungsi membentuk kesatuan secara keseluruhan. $^{7}$

Dalam kamus besar Bahasa Indonesia Departemen Pendidikan dan Kebudayaan menjelaskan system yaitu :

${ }^{7}$ Badadu dan Zain, Dalam Kamus Umum Bahasa Indonesia, ( Jakarta: Pustaka Sinar Harapan), 1994. h 1337 
a) seperangkat unsur yang secara teratur saling berkaitan sehingga membentuk suatu totabilitas; b) susunan yang teratur dari pandangan teori, azas; c) metode pendidikan ( klasikal, individual dan sebagainya). ${ }^{8}$

Menurut beberapa orang pakar yang dikutip oleh Eti Rochaety dkk dalam system informasi pendidikan sebagai berikut:

a. Ludwig, 1997 menyebutkan system adalah seperangkat unsur yang saling berhubungan dan saling memengaruhi dalam satu lingkungan tertentu.

b. A. Rapoport, 1997 menyebutkan system adalah sekumpulan elemen yang saling berhubungan untuk mencapai tujuan.

c. L. Ackof, 1997 menyebutkan system adalah setiap kesatuan secara konseptual atau fisik yang terdiri dari bagian-bagian yang saling mempengaruhi.

d. Gordon B. Davis, 1995 menyebutkan system merupakan bagian-bagian yang beroperasi secara bersama-sama untuk mencapai beberapa tujuan.

e. Raymond McLeod, 2001 menyebutkan system yaitu sekelompok elemen yang terintegrasi untuk mencapai suatu tujuan. ${ }^{9}$

8 Kamus Besar Bahasa Indonesia Departemen Pendidikan dan Kebudayaan, ( Jakarta: Balai Pustaka), 1990. h 849

${ }^{99}$ Eti Rochaety dkk, Sistem Informasi Manajemen Pendidikan, ( Jakarta; Bumi Aksara), 2008. h 2-3

\section{Pengelolaan Pendidikan}

Dalam dunia organisasi, istilah pengelolaan pendidikan dan ada juga istilah manajemen pendidikan. Menurut Suharsimi Arikunto mengemukakan" manajemen pendidikan adalah suatu kegiatan atau rangkaian kegiatan yag berupa proses pengelolaan usaha kerjasama sekelompok manusia yang tergabung dalam organisasi pendidikan, untuk mencapai tujuan pendidikan yang telah ditetapkan sebelumnya agar afektif dan efesien. ${ }^{10}$

Dalam sistem pengelolaan pendidikan harus mampu mengembangkan tujuh standar yaitu ;

1. Standar Isi

2. Standar Proses

3. Standar Kompetensi Lulusan

4. Standar Pendidik dan Tenaga Kependidikan

5. Standar Sarana Prasarana

6. Standar Pengelolaan

7. Standar Penilaian Pendidikan

Pemberian grade nilai menggunakan prinsip, bertanggung jawab, evidence, dan akuntabilitas. ${ }^{11}$

\section{Pengertian Pendidikan Formal}

Istilah pendidikan adalah dari bahasa Yunani yaitu Paedagogik. Paedagogik asal katanya adalah "Pais" yang artinya "anak" dan again yang terjemahannya adalah " membimbing", dengan demikian maka Paedagogik

\footnotetext{
${ }^{10}$ Suharsimi Arikunto, Manajemen Pendidikan, (Yogyakarta; Adityia Media), 2008. h 4

${ }^{11}$ Ibid., h 182-183
} 
bearti " bimbingan yang diberikan kepada anak". 12

Menurut Husub Al-Makhzaji dan Jarij Jarin yang dikutip oleh Hafi Anshari pendidikan adalah usaha untuk memberikan bimbingan terhadap persiapan-persiapan hidup dari anak dalam kehidupannya. Tidak ada seorangpun yang tidak melakukan hal itu kepada anak-anaknya untuk memberikan persiapan-persiapan pada masa depannya.

\section{E. Panti Asuhan}

Panti Asuhan merupakan sebuah lembaga sosial untuk menampung anakanak yatim, anak terlantar yang hidupnya tidak terurus dan tinggal di jalanan sebagai tempat untuk mengembangkan segala potensi yang dimilikinya, dan supaya mereka terpenuhi kebutuhannya baik fisik, rohani dan sosialnya.

Setiap Negara menginginkan agar warga negaranya secara keseluruhan hidup sejahtera. Berdasarkan Depsos RI tahun 2004 bahwa : “ Panti Sosial Asuhan anak adalah suatu lembaga usaha kesejahteraan social yang mempunyai tanggung jawab untuk memberikan pelayanan kesejahteraan social kepada anak terlantar dengan melaksanakan penyantunan dan pengentasan anak terlantar, memberikan pelayanan pengganti orang tua/wali anak dalam memenuhi kebutuhan fisik, mental dan social kepada anak asuh sehingga memperoleh kesempatan yang luas, tepat, dan memadai bagi pengembangan kepribadiannya sesuai

12 Sudirman. N, dkk, Ilmu Pendidikan, (Bandung; Remaja Karya), 1987, h 4 dengan yang diharapkan sebagai bagian dari generasai penerus cita- cita bangsa dan sebagai insan yang akan turut secara aktif di dalam bidang pembangunan nasional". 13

\section{F. Teknik Pengumpulan Data}

1. Observasi

2. Wawancara

3. Dokumentasi

\section{G. Analisis Data}

Pengelolaan pendidikan dalam upaya mewujudkan visi dan misi SMP Plus Pada Panti Asuhan At-Thoiba Pekanbaru yang telah dipatrikan ditempuh dengan menggunakan sistem yang diterapkan oleh kepala sekolah sebagai berikut:

1. Menata sistem upaya kepala sekolah melakukan perencanaan dalam pengembangan program-program pendidikan untuk mencapai dari visi, misi dan tujuan sekolah SMP Plus Pada Panti Asuhan At-Thoiba Pekanbaru.

2. Menata sistem upaya kepala sekolah dalam menerapkan atau merencanakan program jangka pendek, program jangka menengah, dan program jangka panjang.

3. Menata sistem strategi dan program kepala sekolah agar dikembangka secara konsisten mengarah kepada pencapaian misi dan misi sekolah.

4. Menata sistem upaya kepala sekolah dalam melakukan perekrutan dan penempatan guru.

${ }^{13}$ Departemen Sosial Republik Indonesia Tahun 2004, h 14 
5. Menata sistem upaya kepala sekolah dan guru-guru melaksanakan kedisplinan siswa.

6. Kepala sekolah melibatkan komite sekolah secara aktif dalam penyusunan Rencana Anggaran Pendapatan dan Belanja Sekolah ( RAPBS) dan penetapan APBS.

7. Terdapat kegiatan sosialisasi lanjutan tentang hasil pelatihan/ penataran yang diikuti guru dan staf tertentu kepada semua warga sekolah.

8. Menata sistem upaya kepala sekolah dalam melakukan evaluasi terhadap program-program sekolah.

9. Menata sistem upaya kepala sekolah dalam melakukan evaluasi secara kontiniu pendayagunaan tenaga pendidik dan kependidikan.

Untuk mendapatkan data yang lebih akurat dan informasi mengenai hal- hal yang diatas, penulis melakukan observasi dilapangan kemudian wawancara dengan kepala sekolah dan beberapa orang guru sebagai pengelolaan pendidikan di SMP Plus pada Panti Asuhan At-Thoiba Pekanbaru antara lain :

Untuk mengetahui hal ini penulis melakukan teknik wawancara dengan kepala SMP Plus Panti Asuhan AtThoiba pada tanggal 24 Januari 2012 "tentang Bagaimana kepala sekolah melakukan perencanaan dalam pengembangan program di SMP Plus" seperti yang beliau tuturkan sebagai berikut:

"Dalam merencanakan dan menerapkan program pengembangan kurikulum SMP Plus sesuai dengan visi dan misi sekolah atau yayasan yaitu:
"Visi adalah terwujudnya pendidikan At-Thoiba sebagai acuan dalam dunia pendidikan" dan "Misinya adalah ; 1) mempersiapkan generasi yang berilmu dan bertakwa; 2) mengembangkan potensi yag intelektual, emosional dan interaksi siswa; 3) menjadi mitra andalan bagi lembaga/ institusi lain yang mempunyai kepedulian sesama terhadap dunia pendidikan" dimana kurikulum Diknas dan kurikulum program yayasan dipadukan serta bekerjasama masyarakat dan guru-guru yang berpotensi untuk memajukan dan mendukung program sekolah". ${ }^{14}$

Terhadap pernyataan yang diberikan oleh kepala sekolah ini, dibenarkan oleh salah seorang guru yang menjabat sebagai Wakil Kepala Kurikulum ( Guru 1) yang diwawancarai pada tanggal 30 Januari 2012, yang menyatakan:

"Memang kepala sekolah kita merencanakan dan menerapkan program pengembangan kurikulum berdasarkan visi dan misi sekolah dan juga antara kurikulum Dinas dipadukan dengan kurikulum program yayasan agar tercapai tujuan program sekolah"15

Untuk memperoleh keabsahan informasi penulis melakukan wawancara dengan salah seorang komite sekolah pada tanggal 27 Januari 2012 yang menyatakan :

"Tanggung jawab mereka yang tampak oleh saya, karena saya sudah lama tinggal disini, dalam

14 Kepala Sekolah SMP Plus Panti Asuhan At-Thoiba, wawancara 24 Januari 2012.

15 Wakil Kepala Kurikulum SMP Plus Panti Asuhan At-Thoiba, wawancara 30 Januari 2012 
merencanakan dan menerapkan program sekolah kepala sekolah sering melibatkan saya untuk menerapkan program-program sekolah terutama dalam menyangkut Pelaksanaan Kurikulum dan kedisplinan siswa". ${ }^{16}$

Untuk memperoleh informasi yang lebih akurat penulis melakukan wawancara dengan salah seorang guru yang menjabat sebagai Wakil Kepala Humas (Guru 2) pada tanggal 31 Januari 2012 ia menyatakan :

"Alhamdulillah, sudah berjalan dengan baik tinggal kita bersama untuk selalu mendukungnya agar tercapai apa yang kita harapkan"17

Dalam melaksanakan perencanakan dan pengembangan program sekolah SMP Plus Panti Asuhan At-Thoiba adalah tertumpu pada kepala sekolah dan semua Staekholder Sekolah artinya semua guru-guru dan komite sekolah memberikan masukan dalam melakukan perencanaan dan pengembangan program SMP Plus untuk tercapainya tujuan pendidikan.

Menurut analisis penulis dari data yang ada diatas, kepala sekolah dan stakeholder sangat merasa bertanggung jawab terhadap pengembangan pendidikan di SMP Plus Panti asuhan At-Thoiba untuk membantu pendidikan bagi anak yang kurang mampu sehingga mereka mendapat pendidikan dan dapat mengembangkan potensi dirinya, berilmu dan berakhlak mulia.

16 Komite Sekolah SMP Plus Panti Asuhan At-Thoiba, wawancara pada tanggal 27 Januari 2012

${ }^{17}$ Wakil Kepala Humas SMP Plus Panti Asuhan At-Thoiba, wawancara 31 Januari 2012
Sebagaimana yang diungkapkan E Mulyasa bahwa kepala sekolah merupakan seorang manejer disekolah ia harus bertanggung jawab terhadap perencanaan, pelaksanaan, dan penilaian perubahan atau perbaikan program pembelajaran disekolah. Untuk kepentingan tersebut, sedikitnya terdapat empat langkah yang harus dilakukan yaitu menilai kesesuaian program yang ada dengan tuntutan kebudayaan dan kebutuhan peserta didik, meningkatkan perencanaan program, memilih dan melaksanakan program, serta menilai perubahan program. $^{18}$

\section{H. Kesimpulan}

Berdasarkan hasil wawancara dan observasi peneliti dilapangan, serta sesuai dengan pembahasan dalam penelitian ini dapat disimpulkan sebagai berikut:

1. SMP Plus Panti Asuhan At-Thoiba Kecamatan Tenayan Raya Kota Pekanbaru sudah mulai melaksanakan pengelolaan sekolah. Secara umum pengelolaan pendidikan di SMP Plus yang dilaksanakan oleh kepala sekolah terdapat beberapa keunikan keunikan dalam pengembangan pendidikan disekolah tersebut. Seperti dalam pengelolaan tenaga pendidik, maupun kedisplinan siswa dalam mencapai visi dan misi maupun tujuan sekolah khususnya sekolah yang bersipat Panti Asuhan.

18 E. Mulyasa, Manajemen dan Kepemimpinan Kepala Sekolah, ( Jakarta: Bumi Aksara), 2011, h 82 
2. Transparansi kepala sekolah dalam mengambil kebijakan terutama dalam masalah keuangan selalu dibicarakan bersama melalui rapat, bahkan melibatkan komite sekolah dalam pembicaraan RKAS dan RAPBS untuk mencapai kesepakatan. Sedangakan kebijakan menerima murid baru, murid pindahan dari sekolah lain, secara transparan kepala sekolah membicarakan lebih dahulu dengan pimpinan sekolah, sehingga keputusan yang diambil merupakan keputusan bersama.

3. Kreatifitas kepala sekolah dalam mengembangkan program sekolah sudah maksimal yaitu dibuktikan dengan hal-hal sebagai berikut: a) Untuk meningkatkan mutu hasil belajar siswa baik dari segi ilmu umum maupun dari segi ilmu agama dengan memberikan tambahan siang sampai sore hari, untuk pelajaranpelajaran agama seperti Nahwu Shorof, Fikih, Qur'an Hadis dan Bahasa Arab. b) Upaya kepala sekolah meningkatkan kedisplinan siswa dalam proses pembelajaran, c) Untuk meningkatkan kinerja guruguru/ tenaga pendidik terhadap proses pembelajaran.

Dalam mempengaruhi pengelolaan pendidikan formal yang dilakukan oleh kepala sekolah untuk mencapai tujuan dari visi dan misi sekolah SMP Plus Pada Panti Asuhan At-Thoiba Pekanbaru antara lain: a) Sumber daya manusia/ tenaga pendidik; b) sarana dan prasarana; c) keuangan sekolah ( APBS).

\section{Daftar Pustaka}

Alex, Kamus Ilmiah Populer Kontemporer, (Surabaya; Karya Harapan).

Abdul Majid, Perencanaan Pembelajaran mengembangkan Standar Kompetensi Guru, (Bandung; PT Remaja Rosda Karya).

UU No. 20 Tahun 2003 tentang Sistem Pendidikan Nasional, (Bandung; Fokus Media), 2006.

Badadu dan Zain, Dalam Kamus Umum Bahasa Indonesia, ( Jakarta: Pustaka Sinar Harapan), 1994.

Kamus Besar Bahasa Indonesia Departemen Pendidikan dan Kebudayaan, ( Jakarta: Balai Pustaka), 1990.

Eti Rochaety dkk, Sistem Informasi Manajemen Pendidikan, ( Jakarta; Bumi Aksara), 2008.

Suharsimi Arikunto, Manajemen Pendidikan, (Yogyakarta; Adityia Media), 2008.

Sudirman. N, dkk, Ilmu Pendidikan, (Bandung; Remaja Karya), 1987.

Departemen Sosial Republik Indonesia Tahun 2004.

E. Mulyasa, Manajemen dan Kepemimpinan Kepala Sekolah, ( Jakarta: Bumi Aksara), 2011. 